\title{
Symeon and His Followers: Stylitism as a Cultural Trend between Syria and Georgia
}

\author{
The Evidence for Stylites in Georgia: A Summary of the Visual \\ Material
}

One key piece of evidence a number of Georgian Historians and Art Historians contend proves a tangible link between Syria and Georgia in Late Antiquity is the popularity of the cult of Symeon Stylites in the country. It is not always entirely clear whether this devotion is directed towards Symeon the Elder of Qal'at Sem'an or his successor Symeon the Younger of the so-called 'Miraculous Mountain' in the environs of Antioch, but there is clearly a deeply rooted veneration of these saints across Georgia. However, as highlighted in the previous chapter, this issue requires further exploration and cannot be accepted simply on the basis of contemporary beliefs about the past. Therefore there are a series of questions that we must consider in order to examine the veracity of these beliefs: When did the cult of Symeon Stylites enter Georgia? What evidence is there for the veneration of the saint(s)? Is there any archaeological or architectural evidence still extant to support Georgian assertions that stylitism became an accepted ascetic practice amongst Georgian monks in late antiquity through to the Middle Ages?

With the notable exception of the medallion discussed in chapter three, the first figural representations of Symeon Stylites in Georgian art still extant date from the eleventh century and originate in very different regions of the country. Perhaps the most famous Georgian depiction of Symeon is the metal icon currently on display in the Treasury of the Shalva Amiranashvili Museum of Fine Arts in Tbilisi. It was originally part of the liturgical treasure of a church in Laghami village, part of the Mestia Community in Svaneti, and comprises a silver-gilt image mounted on a wooden board measuring $35.5 \mathrm{~cm} \times 23 \mathrm{~cm} .^{1}$ Symeon $^{2}$ is shown in half-bust format nimbed and wearing a monastic hood

1 p. 105, Burchuladze, Nana (ed.), Medieval Georgian Ecclesiastical Art in The Georgian National Museum, Tbilisi, 2012.

2 Lafontaine-Dosogne, following Chubinashvili, reports that the inscription refers to Symeon of the 'Miraculous Mountain', meaning that it is Symeon the Younger and that the inscription dates the icon to 1015, p. 194, Lafontaine-Dosogne, J., 'L'influence du culte de Saint Syméon

(C) EMMA LOOSLEY LEEMING, 2018 | DOI:10.1163/9789004375314_006

This is an open access chapter distributed under the terms of the prevailing CC-BY-NC License at the time of publication. 
with the palms of both hands facing outwards towards the viewer, implying benediction. To the left of the image is the nimbed figure of Anton, Bishop of Tsageri ${ }^{3}$ who stands with an uncovered head to a height of about three-quarters of the way up the pillar shaft. The column is elaborate and stands on a base with three steps, with a large foliate motif half way up the shaft and a stylized capital atop it that again incorporates foliate motifs rather than following one of the classical orders. The border of the icon has leaf-shaped vine-scrolls interspersed with ten busts within circular roundels. At the top centre of the border is a bust of Christ, whilst the others represent saints. The empty background around the pillar and Anton is half covered by an inscription and there are also characters inscribed on the three steps of the pillar. The icon dates to the early eleventh century and from the identity of the donor and the fact that it remained in Svaneti until its removal to the museum in Tbilisi, as well as a well-attested tradition of metal icons in Svaneti, would perhaps argue for its manufacture somewhere in that region.

The second notable representation of Symeon the Younger is believed to date to the eleventh or twelfth century, with Lafontaine-Dosogne placing it like the Laghami icon in the early eleventh century, ${ }^{4}$ and is located far more centrally although the site has traditionally been classified as being in 'the wilderness'. This is the image of Symeon carved on the chancel screen in the main church at the lavra of Shiomghvime. The lavra's Church of St. John the Baptist is believed to date back to the sixth century, but has been extensively altered over the intervening centuries. The origins of the church are believed to date back to the early days of the monastery and this is where the significance of the image of Symeon Stylites is explained. Shiomghvime is a contraction of Shio, the name of one of the (As)Syrian Fathers and mghvime, a Georgian word for a cave. Shio is believed to have been one of the group who accompanied Ioane Zedazneli from Syria to Georgia and who then trekked approximately ten kilometres into the mountains west of Mtskheta to take up residence in an inaccessible cave high on a sheer rock face where, legend claims, he was fed by an dove. A lavra grew up around Shio's grotto and evolved by the Middle Ages into the monastic complex still present at Shiomghvime. The presence of Symeon is explained by reference to the tenth century vita of St. Shio, which

Stylite le Jeune sur les monuments et les representations figurées de Géorgie', Byzantion 41 (1971), pp. 183-196.

3 Tsageri is in lower Svaneti, rather than in the more remote and mountainous region of higher Svaneti where Laghami is located.

4 p. 188, Lafontaine-Dosogne. 
says that Ioane Zedazneli and his disciples visited Symeon Stylites before setting off on their journey to Georgia and it could be a reference to this episode which is depicted on the chancel screen, which also includes a panel showing a scene from the life of St. Shio.

The panel is one of four that were on the bottom section of the iconostasis. The originals are now housed in the Shalva Amiranashvili Museum of Fine Arts in Tbilisi. Three were still in situ in the 1930s when Taqaishvili documented them, with the fourth, more damaged, panel being displayed in another part of the church. ${ }^{5}$ They comprise the Crucifixion, the Symeon Stylites scene, Evagre being led by the dove to discover Shio and a damaged image of the Hospitality of Abraham. Set within a stone framework of a double pomegranate flowerscroll on both sides, with the rounded pattern elongated to form leaf or teardrop shaped scrolls above and below, the inner frame of the panel has a foliate design above and below but the side borders are made up of a basket-weave pattern reminiscent of that seen on Byzantine capitals, including several still extant at Semandağ, the monastery of Symeon the Younger near Antioch. ${ }^{6}$ The central image has Symeon atop his pillar in half bust form. As is common for this iconographical type, the bust is proportionately far larger than the column so that he appears to be bursting out of the pillar from the capital at waist level with no realistic place for his lower torso to be accommodated. He is nimbed and wearing the monastic hood with arms outspread in the posture of an orant. In the lower left of the panel, as with the Laghami icon, is another nimbed figure but in this case it is a female who Taqaishvili identified as the Theotokos. ${ }^{7}$ Lafontaine-Dosogne associates the majority of stylite imagery in Georgia with Symeon Stylites the Younger and so her interpretation of the scene identifies the female figure as Martha, the mother of Symeon the Younger. ${ }^{8}$ The pillar stands on a rocky base, rather than the three steps associated with Calvary, and the drum of the column is inscribed with three crosses as well as other decorative motifs. Behind the column and the figures stands a representation of a large church of the type that Chubinashvili dubbed a Kreuzkuppelkirche, having rejected the term 'domed basilica' when describing this kind of architecture. The typology of the church fits that of the building in which the iconostasis was constructed and so would at first glance seem to represent the lavra

5 pp. 101-103, Taqaishvili, E., 'Antiquities of Georgia', Georgica, 4 \& 5 (1937), pp. 96-116.

6 See the entry for Semandağ on http://architectureandasceticism.exeter.ac.uk At least two capitals with basketwork carving are were still extant when the author visited the site in 1997, as well as stone carved panels with similar interlace motifs.

7 p. 102, Taqaishvili.

8 p. 189 , Lafontaine-Dosogne. 
church rather than Qal'at Sem'an or that of Semandağ, however LafontaineDosogne makes reference to the presence of the church in the scene to confirm her hypothesis that the saint in question is definitely Symeon the Younger by asserting that:

La représentation de Syméon est d'un intérêt tout particulier pour notre propos. La colonne n'est plus isolée, mais se dresse devant l' ensemble des trois églises que comptait le monastère du Mont Admirable, et sainte Marthe, mere du saint, se tient à gauche sur le pilier à degrés qui existe encore actuellement au pied de la colonne. Ceci constitute la prevue irréfutable qu'il s' agit bien de Syméon le Jeune. ${ }^{9}$

Despite this the church in the background of the panel does fit schematically with the main church at Shiomghvime and it could be that, if we accept Lafontaine-Dosogne's assertion that the building is meant to represent the church on the 'Miraculous Mountain', the image is meant to serve a dual purpose and stand for both Symeon's church and that of Shiomghvime at the same time. We must not discount the fact that the lavra sits with the main monastic buildings set into the side of a steep hillside with a sheer rock face honeycombed with caves towering above it, meaning that the complex is accessed by a flight of steps to the west, which is also how the steps on which Martha stands could be construed rather than as a platform from which to communicate with the saint.

Further complication is added by the fact that although the vita of St. Shio that highlights the meeting of Ioane Zedazneli and his followers with Symeon Stylites purports to recount events of the early sixth century, it was written much later and so cannot be taken as an accurate portrayal of late antique events. Haas maintains that the timeline of the vita is somewhat anachronistic because he interprets the visit as being made to Symeon Stylites the Elder who died in $459^{10}$ and therefore if his argument is correct then it is clear that the writer of the vita had a confused grasp of the chronology of late antiquity. Lafontaine-Dosogne associates the visit with Symeon the Younger, as do a num-

\footnotetext{
9 Ibid.

10 p. 95, Haas, Christopher, 'Ioane Zedazneli: A Georgian Saint in the Syrian Ascetical Tradition', in Skinner, Peter, Tumanishvili, Dimitri \& Shanshiashvili, Anna (eds.), Georgian Art in the Context of European and Asian Cultures: Proceedings of the Vakhtang Beridze ist International Symposium of Georgian Culture, June 21-29, Georgia, Georgian Arts and Culture Centre; Tbilisi, 2009, pp. 95-100.
} 
ber of Georgian scholars ${ }^{11}$ and it is clear that this fits the early sixth century time frame historically attributed to the thirteen (As)Syrian Fathers more convincingly and logically than a visit to his forebear. At this point it should be pointed out that both the vita of Symeon the Elder and that of Symeon the Younger make mention of Iberians but we shall discuss that issue further elsewhere in this chapter.

In her work outlining the relationship of Georgia with the cult of Symeon Stylites the Younger, Lafontaine-Dosogne makes an inventory of Stylite imagery in Georgia and can add another chancel screen relief of Symeon Stylites to that of Shiomghvime. Perhaps unsurprisingly given the story recounted above, this relief, though now also in the Shalva Amiranashvili Museum of Art in Tbilisi, originated in the church of Zedazeni, the place Ioane Zedazneli settled on reaching Georgia and after which he is named. The fragment of sculpture has been dated as contemporary with the two examples discussed above as being early eleventh century, but only a portion of the image remains. It shows the saint nimbed and hooded once more, but is a three quarter length view whereby the saint stands in a balcony-like structure that reaches his chest in height. Between the wooden railings of an open balustrade we can see down to the thighs of the saint and below this point his legs and feet are hidden within a large stone capital with the rest of the column below now lost. The saint has his left hand raised in the orant gesture and the right one was presumably the same, but is now missing. The fragment has no other identifying features, leading Lafontaine-Dosogne to conclude that it is impossible to know if the elder or younger Symeon is represented in this case. ${ }^{12}$

Finally she makes a brief inventory of Stylite imagery in frescoes and records early eleventh century frescoes of both Symeon Stylites the Elder and Symeon the Younger in the refectory of the Udabno monastery in David Gareja, a thirteenth century fresco of Symeon the Younger at Shiomghvime and a fourteenth century one of him in the church besides the 'tower-house' of Ubisi. The first two locations are connected to the (As)Syrian Fathers and the third to the Georgian native variant of stylitism, which leads us neatly on to the next point.

\footnotetext{
11 For more on this see below.

12 p. 195, Lafontaine-Dosogne.
} 


\section{When is a Stylite Not a Stylite? A Comparison of Pillars and Tower Houses}

Here it is useful to pause a moment and to consider exactly what the concept of stylitism meant to late antique and medieval Georgian monks. Recent research on the Syrian material suggests that this was not always as clearly defined as later academics have assumed, indeed the sources suggest that even in Syriac the situation was often ambiguous as the Syriac term estuna $\bar{a}$ could mean both 'pillar' and 'tower' 13 and was often used in an interchangeable sense. Added to this, one commentator has observed that:

Several centuries later in Asia Minor, the term stylite could be used for ascetics who did not live on pillars at all. On the contrary, these ascetics lived on top of rock formations that resembled pillars, and yet are referred to in our sources as 'Stylite recluses.'14

Schachner goes on to remark that even though they did not live on a pillar in the same manner as Symeon Stylites, the monks who adopted the lifestyle outlined above often believed themselves to be 'Stylites', as they felt their lifestyle choices to be inspired by Symeon's legacy. This argument is crucial to understanding the Georgian relationship with stylitism because, despite many claims to have a history of 'pillar' saints, there is no conclusive archaeological evidence still extant in Georgia today to support the argument that pillar-dwelling stylites in the manner of Symeon ever lived in the region. On the other hand there is a rich tradition of 'stylites' inhabiting pinnacles of rock or tower-houses and it is this tradition that appears to explain the numerous Georgian references to stylites across both eastern and western Georgia encompassing both Kartli and Egrisi (Map 4).

The most famous site associated with stylites in Georgia today is Katskhis sveti (Katskhi's pillar) in the village of Katskhi, in the district of Chiatura on the River Katskhura. This district lies in Imereti in western Georgia and although physically located to the west, is a region that has historically been closely linked in political and cultural terms with Kartli rather than Egrisi. The 'pillar' is a forty-metre high limestone pinnacle known by local people as 'Katskhi pillar' or 'The Life-giving pillar' and the ruins on the top of it are associated with

\footnotetext{
13 p. 333, Schachner, Lukas Amadeus, 'The Archaeology of the Stylite', Late Antique Archaeology, 6 (2010), pp. 329-397.

14 p. 334, Schachner.
} 


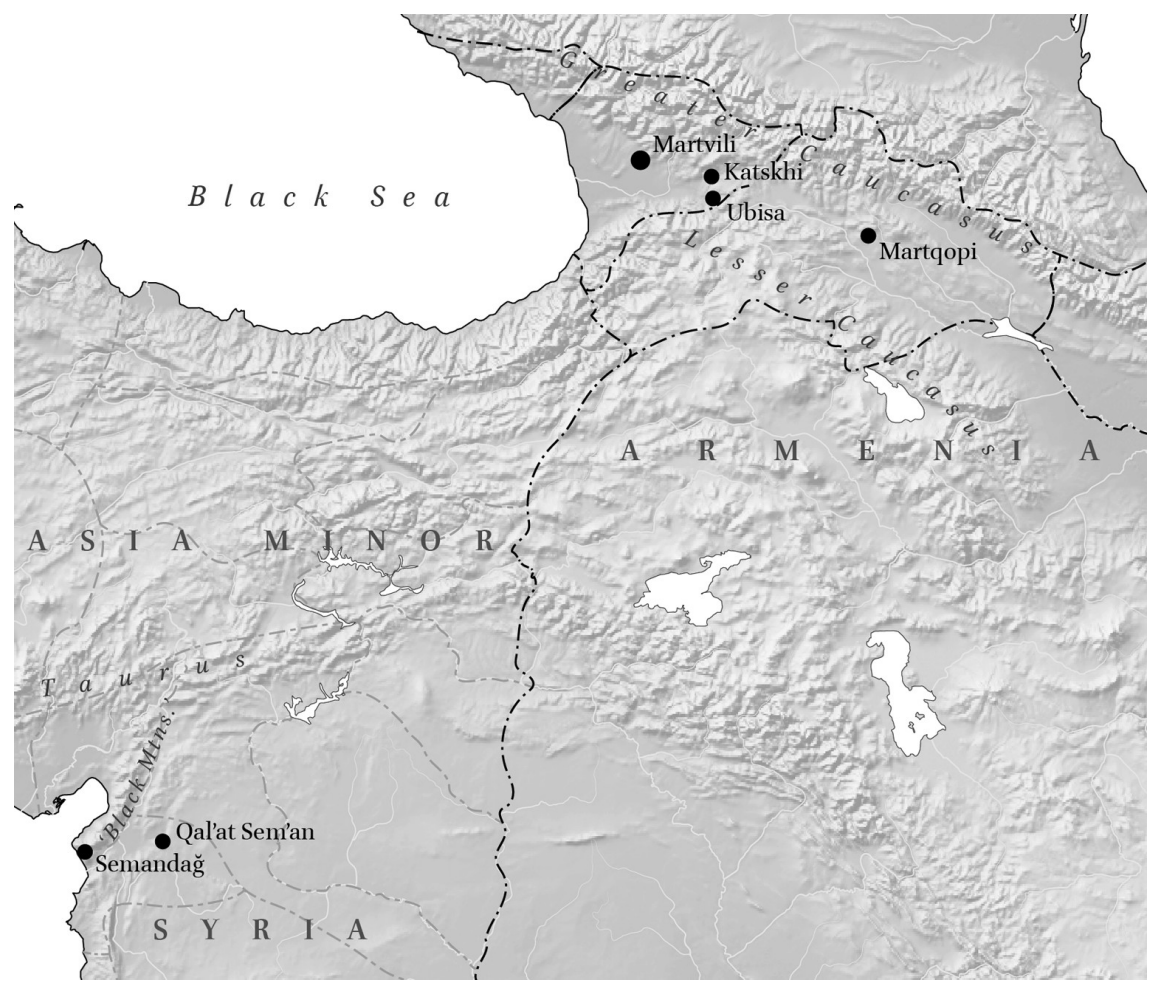

MAP $4 \quad$ Locations in Syria and Georgia associated with Stylites

St. Symeon Stylites. ${ }^{15}$ This site was long attributed to the fifth or sixth century, ${ }^{16}$ making it approximately contemporary with Symeon Stylites and his immediate followers. However recent archaeological survey and excavation at the site has radically altered the chronology of the buildings on top of the pinnacle and now brings the establishment of a small monastery at the site forward to the tenth century:

A small monastery has been identified on Katskhi's "pillar", with the monastery having an economy completely unlike that of $5^{\text {th }}-6$ th century Syrian Stylites, and probably Katskhi's pillar hermit monks followed a different rule to the Syrian Stylites, who followed an extremely ascetic life and a rule on a small pillar that provided only a small platform under the open skies (St. Symeon Stylites the Elder lived like this) as "Spiritual Ath-

15 p. 55, Gagoshidze, Giorgi, 'Katskhis Sveti', Akademia, 1 (2010), pp. 55-68.

16 See for example Lafontaine-Dosogne, p. 186. 
letes". Katskhi's "pillar" has a small monastery where two or three monks from a larger monastery were probably dedicated to serve in small single cells, which were strongly similar to those in Thessaly (Greece) where the Meteora Monastery (12th-16th centuries) was built on an impregnable cliff. ${ }^{17}$

Here Gagoshidze reinforces the point made above by linking this form of 'stylitism' to a disciplined monastic asceticism whereby practitioners isolate themselves from the world by taking up residence on an isolated and difficult to access rocky pinnacle. In this case it could be argued that the hermits are adhering to the spirit of stylitism, without following it to the letter. If we accept this argument, then there is relatively plentiful evidence for 'stylites' in Georgia.

Whilst the dramatic setting of the Katskhi monastery makes this the most famous 'stylite' dwelling in the country, a number of 'tower-houses' are known across the western and central regions of the country. The most famous 'stylite' in Georgian ecclesiastical history is St. Anton Martqopeli, one of the thirteen (As)Syrian Fathers who is believed to have ultimately settled at Martqopi, a site approximately eighteen kilometres north east of central Tbilisi. In the nineteenth century Platon Ioseliani argued that Anton lived at Koshki-Sveti one kilometre east of the monastery at Martqopi in a tower that he built himself and where he dwelt until the end of his life, and Gagoshidze identifies this as being the oldest 'tower' dwelling in Georgia (Fig. 11$).{ }^{18}$ In the last decade researchers restoring the structure have reached the conclusion that the four storey tower probably dates to the eighth or ninth century, rather than to the sixth century as popular belief and earlier scholars had suggested.

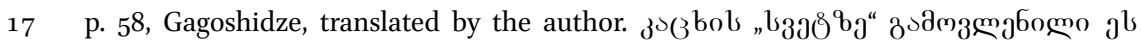

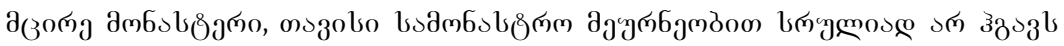

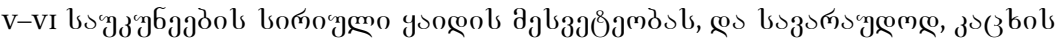

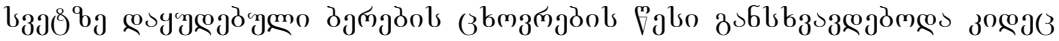

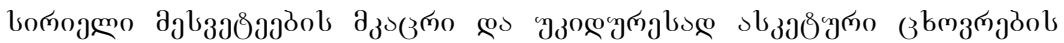

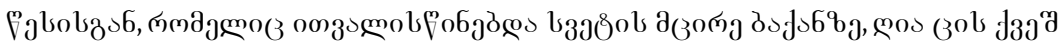

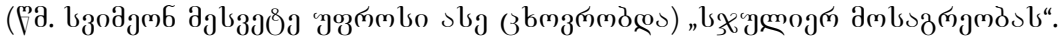

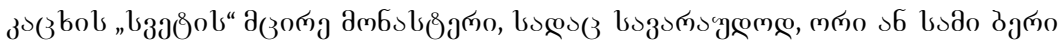

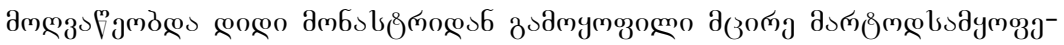

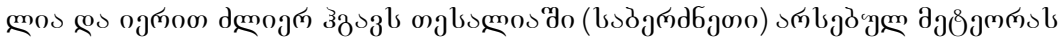

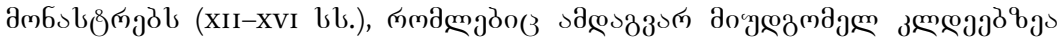
১व 


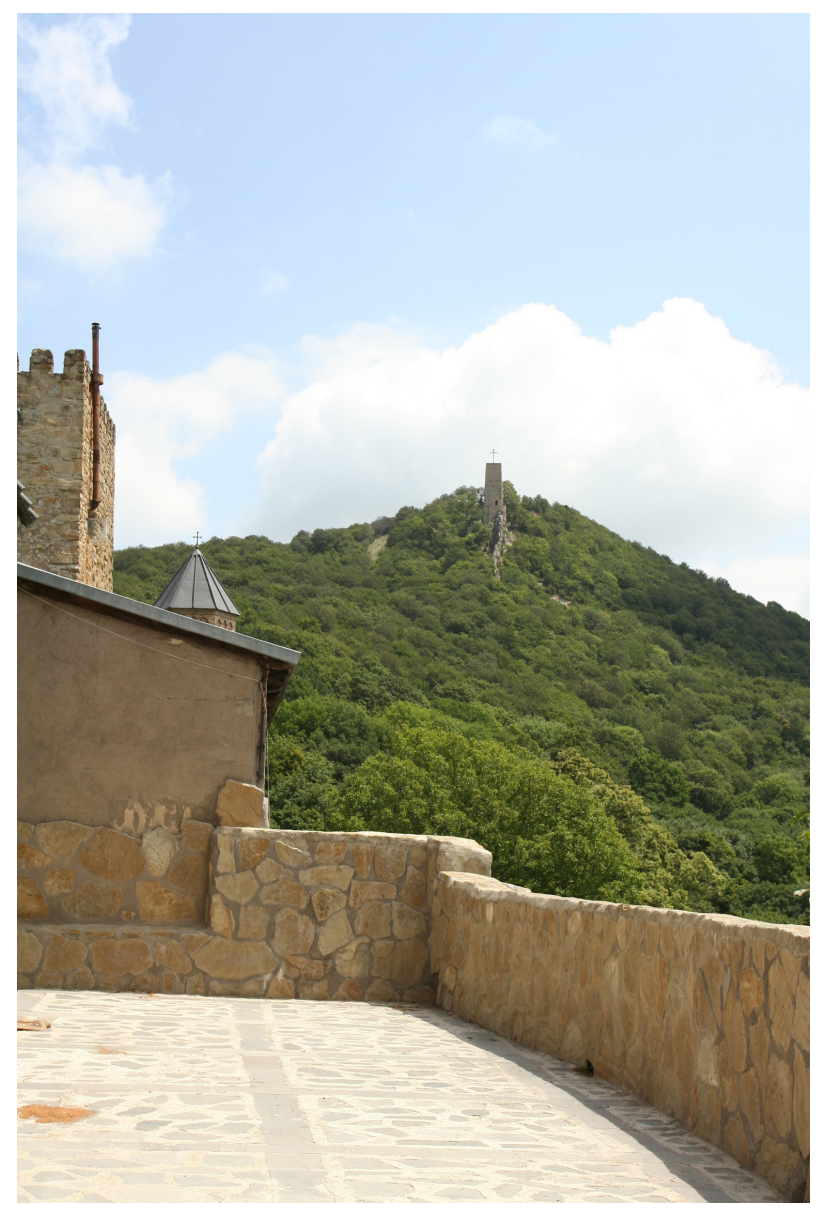

FIGURE 11 The 'Stylite tower' at Martqopi seen from the main monastery

Although its origins are not as early as has been traditionally believed, the tower-house at Martqopi nevertheless remains the earliest example of this kind of monastic dwelling still exant in Georgia. Leaving aside Katskhi for the moment, the next instance of stylitism in Georgia we can trace was at Martvili in Samegrelo in the west, which was located in Egrisi/Lazica. Martvili monastery dates back to the seventh century, but Gagoshidze accepts Tsintsadze's evidence to assign the tower house at the site to the late tenth or early eleventh century ${ }^{19}$ Ubisi monastery in Imereti also possesses a four storey

19 p. 59, Gagoshidze. 


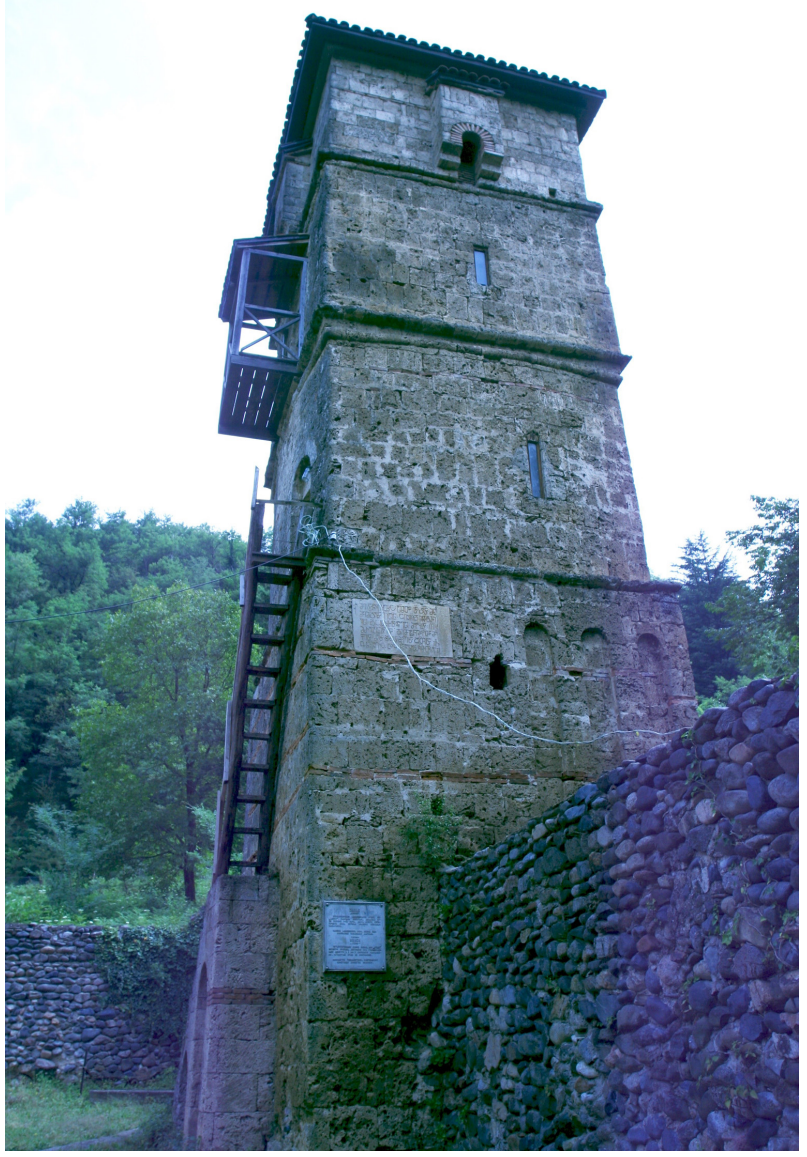

FIGURE 12 'Stylite' tower house at Ubisi

tower-dwelling directly to the east of the church and in this case we can pinpoint its age exactly as an inscription says that the tower was built in the year 1141 in the reign of King Demetre I $\left(1125^{-1156)}\right.$ by Symeon Chqondideli (Fig. 12). ${ }^{20}$ Finally Gagoshidze adds to this list a tower known as "The one who is alone' (martod-mqopeli) in the vicinity of Rkoni monastery in Shida Kartli. He places the building in the later Middle Ages because of its interior construction technique and this accords with Suramelashvili who has assigned it a fifteenth century date. ${ }^{21}$ Having reached the end of the confirmed list of tower-

20 Ibid.

21 Ibid. 
dwellings Gagoshidze does concede that many similar buildings could have existed across Georgia as annexes to monasteries and as an example he points out that there is a strong possibility that a number of buildings at Mravalta at David Gareja were used in this manner. ${ }^{22}$

\section{The First Georgian 'Stylite'? The Case of St. Anton Martqopeli}

Of all the Georgian 'stylite' locations, Martqopi is the one most closely linked in Georgian imagination with the Syrian stylites. Merkviladze asserts that the (As)Syrian Fathers went to be blessed by Symeon Stylites the Younger before setting out on their mission to Kartli ${ }^{23}$ and places this event before he climbed the Miraculous Mountain, thereby saying that as the blessing must have taken place between Symeon becoming a monk in 528 and his ascending the pillar in 540/541, then the (As)Syrian Fathers must have arrived in Kartli between $5^{28}$ and 540. This is all highly speculative, but is nevertheless an interesting way of seeking to reconcile the faith-based hagiographical literature with the historical chronology as by fixing the events in the lifetime of Symeon the Younger rather than linking them to that of Symeon the Elder, then the vitae of St. Anton and St. Shio can be made to fit a plausible historical timeline.

The Syrian relationship with Martqopi has also been emphasised by the belief that St. Anton carried with him the acheiropoieton of the Saviour from Edessa, in this case the keramidion rather than the mandylion. ${ }^{24}$ The keramidion

22 To this list Lafontaine-Dosogne adds another site that she says dates to the eighth to ninth century and is contemporary with the tower at Martqopi at a place called Otlisi. She refers to the work of Tsintsadze as bringing the site to her attention, but despite referencing Tsintsadze throughout his article, Gagoshidze does not include Otlisi on his list of confirmed Georgian 'stylite' dwellings.

23 Cited p. 223 in Matitashvili, Shota, 'Kartuli bermonazvnoba vI-VIII saukuneebshi: Sirieli Mamebi', Sami Saunje 2 (2012), pp. 216-23o.

24 See pp. $393 \mathrm{ff}$. in Abuladze, Ilia, Dzveli kartuli agiograpiuli literaturis dzeglebi, 6 vols., Gamomtsemloba 'Metsniereba'; Tbilisi, vol. 4, 1968. It should also be explained that the mandylion was believed to be the sacred relic created when Christ wiped his face on a towel and it left a miraculous imprint of his features. This artefact was sent with a messenger to King Abgar of Edessa and resulted in him being cured of an unknown ailment. Therefore, as an object that was transformed by the power of Christ, the mandylion was the primary relic. When it was later hidden and the image of the mandylion was transferred to a tile, the keramidion became the secondary relic as it had not made contact with the body of Christ but was in fact the product of a secondary miracle. 
was a miraculous image made by a tile resting against the acheiropoieton rather than the original mandylion itself. ${ }^{25}$ This tradition is in direct contradiction to the beliefs regarding the Anchiskhati image now in the Shalva Amiranashvili Museum of Fine Arts in Tbilisi, which was also believed to be the keramidion in ancient sources, but in more recent history has been associated with the primary relic, the mandylion itself.

The tradition relayed in the vita of the saint says that it is Anton who carried the holy keramidion of Edessa to Martqopi so that it arrived on Georgian soil some centuries before the Anchiskhati image, which was translated to Tbilisi only in the seventeenth century from Ancha in Klarjeti, which had fallen under Turkish control. However the Martqopi icon is no longer extant as it was reputedly hidden by Bishop Giorgi Martqopeli at the time of Tamerlane's invasion and, as he later died without revealing its location, it has never been recovered ${ }^{26}$ Haas remarks that since the story of the acheiropoieton of Edessa gained currency in the early sixth century then this could be a factor seen to reinforce the supposed arrival of the thirteen (As)Syrian Fathers in Kartli at that time. ${ }^{27}$

However, as with the other vitae of the Fathers, the life of Anton was written much later than the events that the manuscript affects to recount and the story becomes much more complicated if we refer to the earliest extant text to discuss the (As)Syrian Fathers. In his work on the Sinai recension (N Sin $5^{\circ}$ ), the earliest manuscript to record the vitae of these figures, Aleksidze comments that there is no mention at all of Anton Martqopeli ${ }^{28}$ rather there were two traditions associated with two other (As)Syrian Fathers; Ezderios Nabukeli, later Samtavneli (also referred to as Isidore) was the 'censer and servant' of the Hierapolis keramidion ${ }^{29}$ and Theodosius of Urhai (Edessa) later came with the Edessa icon (mandylion) to Rekha near Samtavisi, and was thereafter known as Theodosius Rekhali. ${ }^{30}$ In Aleksidze's opinion this means that Anton Martqopeli had nothing to do with the translation of either the mandylion or the keramidion to Kartli and, as such, should be viewed as a disciple of the (As)Syrian

25 For more on the debate as to whether the image of Ancha is the mandylion or the keramidion see Karaulashvili, Irma, 'Anchiskhati: keramidioni hierapolisdan tu mandilioni edesidan?', Mravaltavi 20 (2003), pp. 170-178.

26 p. 23o, Matitashvili, Shota, 'Kartuli bermonazvnoba vi-viII saukuneebshi: Sirieli Mamebi', Sami Saunje, 2 (2012), pp. 216-23o.

27 p. 97, Haas.

28 p. 13, Aleksidze, Zaza, 'Mandilioni da keramioni dzvel kartul mtserlobashi', Academia 1 (2001), pp. 9-15.

29 Ibid.

30 Ibid. 
Fathers such as Dodo Garejeli, whose ascetic zeal led eventually to his name being conflated with those of the original foreign visitors.

In fact given the convincing arguments of Aleksidze that Anton Martqopeli falls into a secondary category of (As)Syrian Fathers and in his view was most probably a native Kartvelian anyway, one is tempted to see an almost circular argument in place whereby a holy man (Anton) decided to move into the koshki (tower) at Martqopi and this unusual form of asceticism was believed to be 'foreign' or 'Syrian'. In light of this the associations with Edessa, the keramidion and the (As)Syrian Fathers could be interpreted as later accretions emphasising the 'Syrianness' of the story of Martqopi. A more recent layer to this narrative has seen, as with the Anchiskhati icon, ${ }^{31}$ a situation where the identification of the holy object has shifted from an association with the secondary artefact (the keramidion) to the primary seat of holiness (the mandylion). Visitors to Martqopi are now told that St. Anton Martqopeli was responsible for bringing the mandylion to Georgia and imagery of this relic is prominent in the contemporary decoration of the monastery at the site. ${ }^{32}$ Monks inform visitors that the relic is still within the environs of the monastic complex waiting until a sufficiently 'pure' person is judged worthy of the honour of recovering this sacred artefact. It is from the observation of the process of contemporary, postSoviet myth-making in the Georgian Orthodox Church that one can perhaps best understand how the strata overlaying earlier foundation narratives came into existence.

\section{The Origins of Stylitism: A Return to Syria}

As Schachner observes in 'The Archaeology of the Stylite', despite the widespread interest in Symeon Stylites and his continued presence as a motif in elements of contemporary culture, surprisingly little archaeological research has been undertaken with the aim of quantifying how many sites are linked to stylites. The best known material is, without question, those monuments linked to the founder of the movement Symeon Stylites the Elder and his successor Symeon the Younger. In both cases the evidence has survived because of

31 Anchiskhati means 'the image of Ancha' in Georgian. However, to make this work more understandable for those unfamiliar with the Georgian language, I use the (technically incorrect) designation of the 'Anchiskhati icon' in this work to maintain clarity. monastic church depicting Anton Martqopeli as the bearer of the mandylion see http:// architectureandasceticism.exeter.ac.uk/items/show/736. 
the relatively remote location on which they elected to set up their columns. It is also clear that in cases such as Symeon the Elder's famous disciple, Daniel the Stylite, we are almost certain never to find physical evidence of his pillar and the surrounding monastic foundation as it was built on the outskirts of fifth century Constantinople and was lost under the expansion of the conurbation some centuries ago. Despite this it is interesting that, until Schachner's 2010 article, there does not appear to have been a concerted effort to compile a list of known stylites and their martyria. In the gazetteer appended to his article stylites are recorded in: Egypt, Arabia, Palestine, Phoenicia, Syria, Cilicia, Osrhoene, Mesopotamia, Adiabene, Paphlagonia, Asia (Minor), Constantinople and Gaul. ${ }^{33}$ Unsurprisingly there are far more stylites recorded in Syria than in any other region and Syria is followed by, again perhaps predictably, Osrhoene and Mesopotamia as the provinces possessing the next largest number of recorded stylites. Schachner's list claims to be definitive until c. 800 and it is perhaps for this reason that we do not find any Iberian stylites on the list as our earliest archaeological evidence of tower-house or pinnacle dwellers in Georgia seems to begin around the eighth to ninth centuries. Alternatively the omission could be because as their lifestyle was more inspired by the stylite movement rather than being true stylitism in its purest sense, they have not been recorded as stylites. Finally the silence relating to Iberia could simply be due to the impenetrability of the Georgian language and the fact that the Georgian saints' vitae have not been as easily accessible to foreign scholars as the Latin, Greek, Syriac and Coptic sources.

One element that has raised questions in the Syrian archaeological record is the prevalence of non-figural stylite imagery, which became increasingly stylised as the motif spread across the Syrian Limestone Massif. ${ }^{34}$ Frankfurter has suggested that this imagery can be linked to the earlier baetyl cults of the region $^{35}$ and this could be one reason why there was an increasing emphasis on the pillar rather than the saint himself as the imagery of stylitism evolved in the wider region of northwestern Syria. ${ }^{36}$ In Georgia where, for the reasons

33 pp. 382-386, Schachner, 'The Archaeology of the Stylite'.

34 For the most comprehensive survey of Syrian stylite imagery see: Peña, Ignace, Castellana, Pascal \& Fernandez, Romuald, Les stylites syriens, Studium Biblicum Franciscanum, 16, Milan, 1987 .

35 p. 18o, Frankfurter, D.T.M., 'Stylites and Phallobates: Pillar Religions in Late Antique Syria', Vigiliae Christianae, 44:2 (1990), pp. 168-198.

36 See the entry for Sheikh Sulaiman on http://architectureandasceticism.exeter.ac.uk where the symbol on the northern side of the western façade of the sixth-century church is a stylised representation of a stylite's column. 
discussed elsewhere in this chapter the 'stylite' tradition is a more fluid concept, nobody has yet attempted an analysis of what, if any, aniconic stylite imagery may be present in the country. Interestingly Gagoshidze noted an equal-armed cross within a roundel carved into the side of the Katskhi rock pinnacle ${ }^{37}$ and more crudely scratched beneath the cross is a pillar that stands on a three-stepped base. The fact that the cross is often shown in Oriental Christian iconography on a three-stepped base that signifies Calvary, we can interpret this image in one of two ways. It is either a schematic reference to the Crucifixion or alternatively is making a reference to the 'stylites' that inhabited the top of the pinnacle. If this carving is interpreted as the latter and viewed as a sign of the 'stylite' atop the pinnacle then we do have one piece of evidence suggesting at least a passing familiarity with the stylite imagery of northwest Syria. However, as mentioned above, it is perhaps unlikely that this imagery would have found the same resonance outside the environs of Syria and Mesopotamia, where the evidence suggests that the practice may have been heavily influenced by pre-Christian fertility cults, most memorably described by Lucian in his satirical work De Dea Syria ${ }^{38}$ where he refers to 'phallobates' sitting atop giant phalli for forty days and nights to ensure the continued fertility of the wider community. If this is the case, then we are more likely to be looking at a stylised Crucifixion scene such as that found at Tell Tuneinir on the banks of the River Khabur in the Mesopotamian region of Syria. ${ }^{39}$

\section{Two Layers of Georgian Stylite Cult?}

At this stage we need to stop and untangle the various strands of this interaction backwards. In the first instance it is indisputable that medieval Georgia saw the establishment of a devotional tradition that venerated Symeon Stylites. All evidence thus far overwhelmingly links this cult with Symeon the Younger rather than Symeon the Elder. This is logical given that Symeon the Younger lived in the sixth century and was strongly associated with Chalcedonian Orthodoxy, which as will be discussed later in this volume, was an image that the Georgian Church was keen to promote after joining the Chalcedonian fold in the early seventh century. On the other hand by dying in 459 , a mere

37 Fig. 8., p. 67, Gagoshidze.

38 Lucian, Trans. Harmon, A.M., 'De Dea Syria', Lucian, vol. 4, Loeb Classical Library 162, Harvard University Press; Cambridge, MA \& London, 1925.

39 See http://users.stlcc.edu/mfuller/AreagArtifactsArt.html (Accessed 28.03.2017) and pers. comm. with Michael and Neathery Fuller. 
eight years after the Council of Chalcedon in 451 , nobody could really claim to know which side the first stylite, Symeon the Elder, may have favoured in this increasingly vicious disagreement. Therefore to venerate him too closely may have been a risk for a group who had been viewed by Constantinople as in theological error until their change of heart. With this in mind we need to separate the evidence and consider first the extent of the contact in the fifth and sixth centuries, before moving on to draw a conclusion as to what may have caused the later medieval flourishing of this cult.

One thing that is certain is that both stylites were known in 'Iberia' (Kartli) within their own lifetimes as Theodoret refers to men coming from this nation to speak with the Symeon the Elder in the fifth century ${ }^{40}$ and there are references to Iberians interacting with both Symeon the Younger and with his mother St. Martha in the sixth century. ${ }^{41}$ This contact with the younger stylite and his mother has long been one of the central planks in the argument for the existence of the (As)Syrian Fathers and is often pointed to as definitive proof that monasticism entered sixth century Georgia from Syria. However this concentration on the vitae of the stylites is misleading; rather than being indicative of the content of a wide number of texts, these references to Iberians are actually extremely rare in late antique Syriac sources. Syrian and Mesopotamian Christians would have known of the conversion of Iberia as Theodoret included the narrative of a 'captive woman' who cured an Iberian queen causing her unnamed husband to see the truth of her faith and thereby adopt Christianity, in his Ecclesiastical History. ${ }^{42}$ Despite this there is no other Syrian or Mesopotamian literary evidence still extant to cast light on the wider extent of dealings between the two regions and, as the previous chapter demonstrated, the archaeological record is equally mute on this account. Therefore if we are looking for any contemporary evidence that the Iberian visitors to Qal'at Sem'an and Semandağ carried anything back with them to Kartli we are left only with the silver medallion from Davit Gareja discussed in the previous chapter.

$40 \quad$ XXVI, 11,13, p. 165 \& p. 167, Theodoret of Cyrrhus, Trans. Price, R.M., A History of the Monks of Syria, Cistercian Publications; Kalamazoo, 1985.

41 Chapters 103, 130, 131, 136 and 253 of the vita of Symeon and chapters 53, 54, 56, 57 and 65 of the vita of St. Martha concern Iberians. See Van den Ven, Paul, La vie ancienne de S. Syméon Stylite le Jeune (521-592), I. Introduction et texte grec, II. Traduction et Commentaire, Vie grecque de sainte Marie, mère de S. Syméon, Indices, Subsidia Hagiographica 32, Société des Bollandistes; Brussels, 1962 \& 1970.

42 pp. 73-75, Theodoret of Cyrrhus, Trans. Walford, Edward, Ecclesiastical History, Samuel Bagster \& Sons; London, 1844. 
On the other hand the Crucifixion/aniconic stylite scene recorded at Katskhi by Gagoshidze finds a close parallel in the panel mentioned above discovered at Tell Tuneinir on the River Khabur in today's Mesopotamian Syria. In addition to the marble Crucifixion panel another similar carved limestone tablet was found in a grave. Missing its upper section, this panel has only one central cross within an elaborate arched doorway that Michael Fuller interpreted as Christ and the gateway to heaven, as in the imagery of Rev. 3:20. Finally a third, heavily weathered, stone plaque found at the same location also recalled the Crucifixion with a cross on a column displayed between two pillars on stepped bases that terminate in lollipop-like circular heads. All three of these artefacts were discovered in the excavation of a monastery at the southwestern edge of the settlement next to the river. However the fragments of a plaque with similar iconography were also recovered in a church at the eastern extremity of the site showing that this was a popular and widespread motif. The eastern church at Tell Tuneinir was active between late antiquity and the Ayyubid period, ${ }^{43}$ whilst the monastery church appears to have remained in use until the final destruction of the settlement by Tamerlane in $1401 \mathrm{CE} .{ }^{44}$ Overall the evidence appears to suggest that these decorative panels belong to the eighth to ninth centuries, or perhaps a little earlier ${ }^{45}$ and this fits neatly with the Katskhi carving if we accept that it was made near the time of the first occupation of the site, which Gagoshidze places at the tenth century but that could also possibly be viewed as contemporary with Martqopi, and therefore seen as an eighth or ninth century foundation. In this way there is a suggestion that there was a link between Mesopotamia and Kartli in this era and, as discussed above, Schachner has remarked on the prevalence of stylite practices in Syria and Mesopotamia up until 8 Oo CE.

If we then turn our attention to the later renaissance of stylite imagery in Georgian sculpture, fresco painting and metalwork, we see that the unifying factor here seems to be that the image of Symeon the Younger experienced remarkable popularity from the early eleventh century onwards. Whilst this later period lies outside the purview of this study it is worth commenting that Djobadze's survey of the Georgian monasteries in the region of Antioch ${ }^{46}$

\footnotetext{
43 https://users.stlcc.edu/mfuller/tuneinir/area3.html (Accessed 28.o3.2017).

44 https://users.stlcc.edu/mfuller/tuneinir/areag.html (Accessed 20.03.2017).

45 This is based on fieldwork studying similar motifs reproduced on stucco decoration at a monastery on Sir Bani Yas island in Abu Dhabi, United Arab Emirates, see Elders and Loosley forthcoming in a volume by Gorgias Press on the excavations at Sir Bani Yas, Abu Dhabi.

46 Djobadze, Wachtang Z., Materials for the study of Georgian monasteries in the Western envi-
} 
seems to point to a decline in the Georgian presence in and around Semandağ from the end of the tenth century onwards. With this in mind it is tempting to suggest that a number of Kartvelian monks returned to their motherland during the early eleventh century and thereby initiated a second wave of stylite devotion within their native land. Naturally this is something that needs further exploration, but the coincidence of the flourishing of the stylite cult in Georgia at a time when it appears that Kartvelian monks were abandoning the Antioch region is certainly striking.

rons of Antioch on the Orontes, Corpus Scriptorum Christianorum Orientalium 372, Subsidia 48, Louvain, 1976 and Djobadze, Wachtang, Archaeological Investigations in the Region West of Antioch On-The-Orontes, Franz Steiner Verlag Wiesbaden Gmbh; Stuttgart, 1986. 